\title{
Shared Responsibility and Labor Rights in Global Supply Chains
}

\author{
Yossi Dahan ${ }^{1} \cdot$ Hanna Lerner ${ }^{2}$ (D) Faina Milman-Sivan ${ }^{3}$
}

Received: 12 January 2021 / Accepted: 26 October 2021 / Published online: 10 November 2021

(C) The Author(s), under exclusive licence to Springer Nature B.V. 2021

\begin{abstract}
The article presents a novel normative model of shared responsibility for remedying unjust labor conditions and protecting workers' rights in global supply chains. While existing literature on labor governance in the globalized economy tends to focus on empirical and conceptual investigations, the article contributes to the emerging scholarship by proposing moral justifications for labor governance schemes that go beyond voluntary private regulations and include public enforcement mechanisms. Drawing on normative theories of justice and on empirical-legal research, our Labor Model of Shared Responsibility introduces three main claims: First, that responsibility for protecting and promoting labor standards in global supply chains should be shared by all private and institutional actors involved (whether directly or indirectly) in the production and distribution processes. Second, we offer a normative model for allocating responsibility among the various actors, based on five principles: connectedness, contribution, benefit, capacity, and power. Last, we demonstrate how the normative model could be implemented through various national and international institutional mechanisms.
\end{abstract}

Keywords Global justice · Shared responsibility · Labor rights · Global supply chains · Globalization · Transnational corporations $\cdot$ Transnational production networks $\cdot$ Sweatshops $\cdot$ Labor law $\cdot$ Corporate social responsibility $\cdot$ International labor organization

\section{Introduction}

As the COVID-19 virus continues to spread worldwide, workers in global supply chains (GSCs) are among those affected most by the pandemic. Lockdown measures intended to slow international infection rates as well as declining consumer demand have further worsened production workers' already devastating labor conditions, especially in developing countries, and particularly in

Hanna Lerner

hanni@tauex.tau.ac.il

Yossi Dahan

yossi.dahan88@gmail.com

Faina Milman-Sivan

fmilman@law.haifa.ac.il

1 Law Faculty, College of Law and Business, Ramat-Gan, P.O. Box. 852, 5110801 Bnei Brak, Israel

2 School of Political Science, Government and International Affairs, Tel Aviv University, P.O. BOX 39040, 6997801 Tel Aviv, Israel

3 Law Faculty, University of Haifa, 199 Aba Khoushy Ave., Mt. Carmel, 3498838 Hafia, Israel buyer-driven, labor-intensive sectors such as garments, toys, and electronics (Anner, 2020; Chen, 2020; WRC, 2020). Yet even before the pandemic's outbreak, sweatshop workers worldwide were laboring under harsh conditions. Despite universal support for the idea that workers should enjoy basic labor rights - as reflected in widespread national regulations and a long list of international conventions and bilateral and multilateral trade agreements-millions of production workers around the world continue to toil for excessive hours, be paid less than the minimum wage, and endure routine infringement of their basic labor rights (Anner, 2019; Sobel-Read, 2014).

In this article, we tackle this conundrum by focusing on the question of responsibility and, more particularly, on the question of identifying the actors-whether individuals or institutions-who are responsible for the dire work conditions in GSCs ${ }^{1}$ and who should be held responsible for remedying the violations of labor standards and for protecting and promoting workers' rights. The acknowledgment that such responsibility should not be shouldered by a single actor-whether the lead firm, a national government, or

\footnotetext{
${ }^{1}$ This article uses the general term global supply chains, referring especially to transnational production networks in labor-intensive areas such as apparel, toys, and electronics.
} 
any particular international organization-has been shared by recent scholarship in global labor governance, business ethics, management, political economy, development, and international labor law (Ashwin et al., 2020; Bair et al., 2020; Blasi \& Bair, 2019; Anner et al., 2013; Schuessler et al., 2019; de Bakker et al., 2019; Soundararajan et al., 2019; Soundararajan et al., 2021; Overdevest and Zeitlin, 2012; Van Buren et al., 2021; Helfen et al., 2018; Levy, 2008; Dahan et al., 2016; Barrientos, 2013). Most of these studies point to the need to move our thinking beyond the familiar divide between private and public regulations. By and large, however, the existing literature that concerns labor in GSCs focuses mainly on measuring the efficacy of existing (primarily private) labor regulatory schemes (e.g., Lee et al., 2017; Locke, 2013; Lund-Thomsen \& Lindgreen, 2014) and on empirical investigations of key factors shaping labor conditions. Such analyses tend to focus on inter-firm power dynamics or buyer-supplier relationship (e.g., Gereffi, 2004, 2018; Lakhani et al., 2013; Bartley \& Egels-Zandén, 2015; Barrientos, 2013) or on the sociopolitical, legal, economic, and cultural contexts within which global production networks are embedded (Coe \& Yeung, 2018; Coe et al., 2008; D'Cruz et al., 2021; Levy, 2008).

Our article contributes to this emerging multi-disciplinary discussion on labor in the globalized economy by proposing a novel normative framework of shared responsibility for promoting and protecting labor rights in GSCs: A Labor Model of Shared Responsibility (LMSR). By drawing heavily from moral philosophy and political theory, yet also from the empirical economic, legal, and political realities of global labor, the article offers moral justifications for labor governance schemes that emphasize public enforcement mechanisms alongside private regulations. Moreover, LMSR, as a normative model, could serve as a helpful framework for evaluating existing and proposed regulatory mechanisms aimed at protecting and promoting labor standards.

The LMSR addresses three central questions. First, who are the actors that should share responsibility for labor standards in GSCs? In contrast to the traditional legal liability model of responsibility, which usually seeks to identify one actor as primarily responsible for harm done, we propose a shared conception of responsibility. Given the existing conditions of the global economy and the dynamics within global production networks (Helfen et al., 2018; Miller, 2010; Sydow et al., 2021), we argue, all actors who participate in the joint activity of production or who affect, directly or indirectly, the labor conditions of workers should share responsibility for labor rights in GSCs.

The second question concerns the allocation of shared responsibility among the various actors. We do not claim that responsibility for protecting and promoting labor rights should be distributed equally, nor that it is a zero-sum game. Instead, we argue that the "responsibility pie" should be divided among the various actors in different ways according to the differing circumstances. Our analysis rests on a practice-dependent relational approach to justice, contending that principles of distributive justice cannot be formulated or justified independently of the practice they regulate (Rawls, 1971; Sangiovanni, 2007; Walzer, 1983). The allocation of responsibility, thus, should be based on a set of five general moral principles that derive from considerations specific to the practice of labor in GSCs: (1) the connectedness between the actors; (2) the contribution to the creation of the unjust situation; (3) the benefit that actors may obtain as a result of the rights' violation; (4) the actors' capacity to provide immediate assistance and remedy the harm done; and (5) the power relationship between the actors.

Third, we turn to the question of implementation. The LMSR is presented here as a regulatory ideal, and its implementation depends on the different political and economic circumstances in which it is applied. Nevertheless, the article offers preliminary guidelines for prioritizing among the principles depending on the specific circumstances of rights violations.

The LMSR presented in this article reveals the existing "responsibility gap" that characterizes many GSCs, between, on the one hand, the responsibilities recognized and enforced by existing legal and political national and transnational arrangements and, on the other hand, the moral responsibilities that some actors involved in GSCs should bear. Such a responsibility gap is most evident in the cases of TNCs and home states (where the brand's management resides), which currently shoulder significantly less legal responsibility for protecting and promoting labor rights in GSCs than is morally warranted by LMSR. Narrowing the responsibility gap requires adjusting existing regulatory global frameworks and translating moral duties into binding, enforceable, and legal commitments. In the last section of the article, we discuss the political feasibility of such steps and propose further institutional mechanisms that could implement our normative model.

The article is structured as follows: The following section situates our argument within existing literature and highlights its contribution to emerging discussion in various fields of study, including management and business ethics, political theory, global labor governance, and international labor law. Next, we present the LMSR according to the three questions described above. The article concludes by discussing the institutional implications of our normative model and by proposing avenues for further research. 


\section{Rethinking Responsibility for Global Labor Standards}

Responsibility is a complex concept that philosophers and political theorists have explored in various contexts, including the field of global justice (Barry \& Øverland, 2016; Miller, 2007; Young, 2004, 2010). However, these discussions rarely engage with business ethics literature and do not address the particular puzzle of responsibility for upholding labor rights in GSCs as a separate normative question. Similarly, normative analysis of the morality of sweatshops and the ethics of GSCs tends to draw on theories of freedom, autonomy, and exploitation (Mayer, 2007; Powell \& Zwolinski, 2012; Preiss, 2019; Snyder, 2008; Sollars \& Englander, 2018), rarely addressing the specific question of who is responsible for the violations of labor standards.

By contrast, studies that more directly consider questions of labor governance in GSCs tend to rely on empirical and conceptual analyses of labor relations and labor governance mechanisms in the globalized economy. In recent years, this scholarship has begun to move beyond the commonly held dichotomy between private and public regulations, which has underpinned the literature as well as most labor governance schemes in the last three decades.

During the 1990s, rising criticism of sweatshop conditions and reported labor rights violations in well-known transnational supply chains led to the rapid growth of various forms of private labor regulations, generally framed in terms of Corporate Social Responsibility. These include individual companies' Codes of Conduct and other voluntary monitoring and auditing mechanisms internal to GSCs (Lund-Thomsen \& Lindgreen, 2014; Lund-Thomsen, 2020; Rasche, 2010; Rodrigez-Garavito, 2005; Bair \& Palpacuer, 2012; Bartley, 2005; Eliot \& Freeman, 2003; Jenkins 2005; Locke, 2013). Over the years, a broad infrastructure of industry-wide codes, standards, and principles for corporate responsibility was developed, including the notable UN Global Compact (UNGC) and a range of monitoring initiatives such as Social Accountability International (SAI) and the Fair Labor Association (FLA). Even the International Organization for Standardization (ISO) began developing international standards on social responsibility, including standards regarding labor practices (Waddock, 2008, p. 91). By and large, such private regulatory schemes spurred a growing debate over their efficacy, as evidence for their limited impact on global labor standards became apparent (Locke, 2013; Barrientos \& Smith, 2007; O'Rouke, 2003). Particular scholarly attention was given to John Ruggie's widely accepted UN Guiding Principles for Business and Human Rights (UNGP), endorsed by the UN Human Rights Council (HRC) in 2011 (OHCHR 2011), which reinforced the nonbinding responsibility of firms and were similarly criticized for their limited impact on workers' rights (Dahan et al., 2016; Rasche \& Waddock, 2021). Many labor governance scholars and activists viewed private regulations not only as inadequate but also as preempting and crowding out more stringent forms of public regulation intended to secure labor standards in GSCs (Bartley, 2005; Locke et al., 2009; Gereffi, 2018; Jenkins 2005; O'Rourke, 2003, 2006; Seidman, 2007; Posthuma \& Nathan, 2010).

At the same time, a parallel discourse emerged in the international labor law literature, which debated the efficacy of public regulations. A growing number of legal scholars observed that the traditional state-centric legal approach no longer fits the economic, legal, and political realities of the globalized labor market. Operating under conditions of a "race to the bottom" and "regulatory chill" caused by global competition over capital and jobs, the nation-state's ability to protect core workers' rights within its territory had weakened (Langille, 2003; Hepple, 2005; Stone, 2008; Dahan et al., 2016; Deva et al. 2013). Criticism was also raised against "soft" regulatory standards developed by international and intergovernmental organizations, such as the ILO's core labor standards or the Organization for Economic Co-operation and Development (OECD) Guidelines for Multinational Enterprises (e.g., Alston, 2004). Even proposals for promoting labor standards through the WTO and international trade agreements (Barry and Reddy 2008) met with skepticism and limited evidence for success in reforming labor conditions in developing countries (Agusti-Panareda et al. 2015; Melo Araujo, 2018). Given the persisting "governance gap" in the regulation of global labor, a broad recognition emerged among scholars concerning the need to combine both public and private regulations, on both national and transnational levels, to address the challenge of labor standards in the global economy (Compa, 2008; Distelhorst et al., 2015; Kolben, 2015; Ruggie, 2014).

The search for new solutions, particularly in the laborintensive global garment industry, led the literature on labor governance, industrial relations, and business ethics to focus its attention on new forms of collaborative governance mechanisms, which rest on coordination between different types of actors across the production network. Most studies have focused on empirical investigations of the emergence and impact of such collaborative schemes. Examples of such initiatives include Global Framework Agreements conducted between firms and global union federations (Fichter et al., 2011; Helfen \& Fichter, 2013) and various forms of multi-stakeholder initiatives (MSIs), generally comprised of industry-based inter-firm collaboration (Bakker et al., 2019). Other Transnational Industrial Relations Agreements (TIRAs) coordinated labor relations on both multi-firm and firm-union levels (Ashwin et al., 2020), as exemplified in the Accord for Fire and Building Safety in Bangladesh (Bair 
et al., 2020; Donaghey \& Reinecke, 2018) and the Action Collaboration Transformation (ACT) living wages initiative (Ashwin et al., 2020). Normative discussion of these new developments in labor governance has often drawn from democratic theories (Mena \& Palazzo, 2012), Habermasian discourse ethics (Gilbert \& Rasche, 2007), or experimentalist governance and deliberation theories (Soundararajan et al., 2021; Soundararajan et al. 2019). A recent study even proposed a new framework of "network social responsibility" for promoting core labor standards through management mechanisms of multi-employer relations in global value networks (GVNs) (Helfen et al., 2018).

While offering a detailed empirical analysis concerning the driving forces underpinning the evolution of different labor governance schemes and a thorough examination of their effectiveness, the current literature refrains from providing a normative justification for the allocation of responsibility among the different private and institutional actors involved, either directly or indirectly, in global production networks. Our article aims to fill this lacuna and contribute to the growing scholarship by proposing a comprehensive morality-based theory of shared responsibility for the protection and promotion of workers' rights in the particular context of labor-intensive GSCs.

The concept of "shared responsibility" has been the subject of increasing attention from political and legal theorists as accelerated globalization processes have revealed the limited ability of individual states or actors to tackle various political and legal problems ranging from global warming to humanitarian aid. ${ }^{2}$ In recent years, the idea of shared responsibility has been applied in various national, international, and transnational court cases, particularly in tort law, environmental law, and human rights law (World Economic Forum, 2015). Iris Marion Young was one of the few political theorists to analyze shared responsibility in the context of global labor (Young, 2004; Young, 2010; see also Van Buren et al., 2021; Aßlander 2020). Her "social connection model of responsibility" rests on the assumption that political responsibility for remedying the structural injustice of sweatshops should be shared by the entire network of socially connected agents involved in the global production of services and products (Young, 2004). Nevertheless, she highlighted sweatshop conditions as one type of structural injustice among others in various areas of life and fields of law while ignoring the special type of relationships embedded in labor relations, and the unique moral and legal implications raised by existing national, regional, and international regulations of workers' labor conditions in GSCs (Dahan et al., 2011). In the rest of this article, we follow

\footnotetext{
2 See, for example, Young (2007); Miller (2001); Salomon (2007). Shares: http://www.sharesproject.nl/.
}

Young's general approach but present an alternative model of shared responsibility, one that pays particular attention to the unique features of labor relations and the political, legal, and economic contexts in which GSCs currently operate.

Before delving into the details of the model, we offer a final introductory remark concerning the minimum threshold of core labor rights and basic working conditions used in this article. For the purpose of this discussion, we propose a minimum threshold shared by most countries around the world (ILO, 2019), consisting of the four core labor rights included in the 1998 ILO Declaration on Fundamental Principles and Rights at Work: (1) the freedom to organize and the right to collective bargaining; (2) the prohibition of forced labor and compulsory work; (3) the prohibition of child labor; and (4) the prohibition of discrimination in employment and professions (ILO, 1998). In addition, our minimum threshold standard includes basic working conditions concerning health and safety, time regulations (e.g., working hours, weekly rest), and wages (such as overtime regulation, deductions, and a living wage). Most of these standards are anchored in national regulations.

\section{The Labor Model of Shared Responsibility: Which Actors Share the Responsibility?}

Following Young, we similarly define labor conditions in GSCs that violate the minimum threshold of workers' rights as cases of structural injustice. These unjust global structures are reproduced by large numbers of people acting according to normally accepted rules and practices, and their potentially harmful impact cannot be traced back directly to particular contributors (Young, 2010, p. 100). We agree with Young that since no single actor is capable of remedying sweatshop conditions in the globalized economy completely, all actors contributing to the processes that yield unjust outcomes should bear responsibility for addressing the structural injustice (Young, 2010, p. 105). ${ }^{3}$

Generally, structural injustice in GSCs occurs on two levels (Miller, 2010): the interactional level, where labor standards are violated in the interaction between individual players within GSCs (e.g., lead firms, suppliers, and workers), and the institutional level, where international institutions regulating the global economy (e.g., IMF, WTO) or intergovernmental trade agreements determine the balance of power both between labor and capital and between developed and developing states (Brishen, 2016; Ebert \& Novitz, 2020; Risse \& Wollner, 2019). Such multilevel approach

\footnotetext{
${ }^{3}$ Our conception of shared responsibility goes beyond the traditional legal distinction between joint and several liability (Lunney et al., 2017, 272).
} 
is similarly supported by the growing body of research on labor within the Global Production Network framework, which takes an "all-inclusive approach" (Coe \& Yeung, 2018; Sydow et al., 2021) when exploring factors contributing to "network responsibility" toward social and sustainable practices (Helfen et al., 2018).

Based on a similar holistic perspective, we argue that all actors who participate in the joint activity of production or affect the labor conditions of workers, whether directly or indirectly - on both interactional and institutional levelsshould be held responsible (albeit not equally) for the protection and promotion of labor standards and for remedying labor rights violations. More particularly, these actors include:

- Actors on both interactional and institutional levels, including individual actors directly involved in the process of production (e.g., workers, managers, individual subcontractors);

- Private entities that may have a direct or indirect influence on the production process, including, for example, private corporations and auditing companies;

- Public institutions on both national and international levels, including local governments, brand-hosting governments, and relevant international organizations that affect the economic structure within which GSCs operate (such the ILO, the WTO, and the World Bank);

- Consumers, who are a necessary component of any practice of production (Brock, 2016; Kolben, 2019; LawfordSmith, 2018).

The next crucial question concerns how the shared responsibility should be allocated among the various actors.

\section{Five Principles of Responsibility Allocation}

In the last three decades, a growing discussion has emerged in the political theory literature regarding the right set of principles for assigning responsibility to particular agents, whether individuals, organizations or governments, for remedying bad situations, usually involving deprived and suffering parties. The need to assign responsibility usually arises when no single agent or institution is formally designated as responsible for remedying the situation. Such cases often occur in the international arena, where formal responsibility for suffering is rarely acknowledged or enforced. Political philosophers such as David Miller and Christian Barry developed different sets of principles for allocating shared responsibility for global problems, focusing mostly on issues of injustice and poverty (Barry, 2003; Miller, 2001, 2007). These theories are generally framed in broad and general terms and refrain from considering specific conditions of particular practices, such as labor in transnational production and supply chains. Iris Young's "social connection model of responsibility" followed this trend and proposed parameters for distributing political responsibility for addressing sweatshop conditions. Her four parameters were based on the agent's position in the social structure, including considerations of power, privilege, interest, and collective ability to remedy the situation (Young, 2010, pp. 146-147). However, Young's analysis did not refer to the complex empirical reality of global labor and did not take into consideration existing national or international labor regulations (Dahan et al., 2011). Moreover, she focused on political responsibility, defined in Hanna Arendt's terms of collective action by citizens pressuring their governments to change their trade policies, or by forming transnational anti-sweatshop movements (Young, 2010, pp. 123-125).

In contrast to Young, the goal of our LMSR is twofold: First, the model aims to identify the "responsibility gap" that exists between the formal responsibilities recognized and enforced by the existing legal and political national and transnational arrangements and the moral responsibilities that actors involved in GSCs should bear. Second, the LMSR seeks to identify those actors who may have more responsibility than others by providing preliminary guidelines for measuring those actors' different degrees of responsibility for protecting and promoting labor rights in the global economy. "Having more responsibility" implies that, morally, an actor who bears a greater degree of responsibility should do more to discharge his/her responsibility. Greater moral responsibility may also be translated into legal commitments, namely the creation of legally binding duties, as discussed in the last section of this article.

The next sections define the five principles of responsibility allocation proposed by our model and discuss the justifications underpinning these principles.

\section{Connectedness}

The principle of connectedness refers to the existence of a special relationship between people that generates unique moral obligations. In contrast to obligations toward anonymous others, the obligations that arise from connectednessalso termed "associative duties"- carry extra moral weight (Scheffler, 2001). In other words, the principle of connectedness affirms that agent A's responsibility to alleviate the hardship of agent $\mathrm{B}$ depends on the bond that exists between them (Haydar, 2005), which can be based on family relations (Barry, 2003; Reader, 2003), shared identity (Scheffler, 2001) or on voluntary commitments, joint activities, or 
shared institutions and practices. Participants in GSCs are part of the joint activity of production and distribution of specific products, and for this reason they have a responsibility to protect and remedy the results of the violation of basic workers' rights. (Barry, 2003). ${ }^{4}$

In GSCs, different types of connectedness may exist on both interactional and institutional levels. In all cases, however, the general idea applies: the stronger the connection (and hence the moral bond), the greater the responsibility.

On the interactional level, labor law usually recognizes a significant degree of connectedness between employers and employees, entailing an intricate web of mutual responsibilities and rights whereby workers enjoy special protection and status. Legally, labor contracts are usually defined as "relational contracts." They are distinguished from shortterm transactional contracts describing a precise transaction of money and goods, covering a one-time-only exchange of an easily commoditized good for cash and including neither altruism nor necessarily any future cooperation. Parties to relational contracts, by contrast, develop long-term relationships based on trust and solidarity that far exceed the terms of the original document (Bird, 2005; Macneil, 2000).

In cases of formal employment contracts, employers' responsibilities toward their workers are easily recognizable. However, it is noteworthy that well-regulated markets, national labor regulations often recognize employers' responsibilities toward their workers even when no formal employment contract was ever signed. ${ }^{5}$ Rather, these responsibilities are based on factors such as management's control of production quality or forms of existing supervision of the production process.

Given the new reality of transnational production chains, including outsourced and offshored work, the traditional legal definition of employer-employee relations can no longer serve as the sole criterion for determining the degree of connectedness between participants in the joint activity of production. Instead, lead companies could be characterized as "employer-like," as determined, inter alia, by their level of supervision of the production process or control of production quality (Gereffi \& Frederick, 2010; Locke \& Samel, 2018). Such connections are stronger than connections between workers and actors outside the production process, such as consumers, or between workers and others within the production process who could not be described as "employer-like," such as vendors.

\footnotetext{
${ }^{4}$ Miller refers to this principle as the community principle (Miller 2001, p. 462).

5 For example, US labor law recognizes the option of joint employment based on the economic realities of the worker's relations. The potential joint benefit from the worker's production is one of the considerations recognized by the court. See Zheng v. Liberty Apparel Co., 355 F.3d (2d Cir. 2003).
}

On the institutional level, different types of special relations that exist between governments and workers, stemming from the worker's residency or citizenship, for example. Another type of institutional connectedness exists between the workers and the brand's home government, which should bear greater responsibility than governments with no such connection. In the same way, states that are parties to labor or trade agreements are akin to partners in the cooperative scheme and, thus, have a responsibility toward workers who suffer as a result of those arrangements (Beitz, 2004; James, 2012; Pogge, 2002).

In general, the connectedness principle inserts a normative meaning to the notion of embeddedness, which gained prominence in recent GPN scholarship (Coe et al., 2008; D'Cruz et al., 2021; Henderson, et al., 2002; Hess, 2004; Lashitew et al., 2020; Noronha et al., 2020). Since moral obligations exist between actors who are connected to each other in special relationships, the actor's embeddedness level may indicate the degree of his/her moral commitment and, thus, responsibility, especially when embeddedness is defined in territorial or in network terms (Burt et al., 2017; Hess, 2004; Noronha et al., 2020). According to Hess, network embeddedness is a product of a trust-building process, which tightens the connections between network agents and, thus, generates more reliable and stable relationships within the network (Hess, 2004, p. 177), for example, between the lead firm and other business and non-business partners. If network embeddedness is viewed as a type of connection, the same logic holds: as network embeddedness increases, the moral commitments between the network members are more significant, and so is their responsibility toward each other.

\section{Contribution}

The contribution principle refers to the causal connection between the agent's actions or omissions and the negative results that occur because of these actions/omissions. The agent is, therefore, responsible for remedying the injustice to which he contributed.

While intention is not considered a necessary condition for assigning responsibility, the agent's responsibility rests on the assumption that, given the circumstances, a reasonable person should have been able to foresee the consequences of his/her actions or lack thereof. We follow here Christian Barry's definition, according to which agent A is viewed as contributing to agent B's deprivation if and only if (1) A's conduct was causally relevant to it and (2) A's conduct did not merely allow a causal sequence that had antecedently put B under threat of acute deprivation, but rather initiated, facilitated, or sustained it (Barry, 2005; Barry \& Øverland, 2016). In the context of labor, determining the extent of an agent's contribution to workers' unjust conditions in the 
global supply chain is not an easy task. Many labor rights violations occurring in global production chains are committed not directly by the corporations themselves but by their subcontractors and suppliers. Nevertheless, subcontractors and suppliers are usually part of the extended production chain that TNCs have initiated, facilitated, and supported. In this sense, corporations have contributed to the unjust labor conditions in their supply chain, even if not directly. This involvement makes them accomplices that knowingly contribute either to the wrongdoing itself or the perpetrator's ability to carry out the wrongdoing (Wettstein, 2010).

Powerful actors in global production chains often oppose such an approach. For example, some TNCs refused to acknowledge their contributing responsibility to the fire that broke out in the Tazreen Fashion factory in Dhaka, Bangladesh, in 2012, causing 117 deaths and injuring more than 200 others. The factory manufactured clothes for various companies, including Walmart (Greenhouse, 2012), which was criticized for knowing about the factory's unsafe conditions yet blocked efforts to improve its electrical and fire safety due to greater costs. For that reason, and despite its initial denial, Walmart was considered responsible for the disaster.

Barry argues that in evaluating such cases, we must distinguish between three different application standards for the contribution principle:

1. The burden of proof: does it fall on Walmart or its critics?

2. The standard of proof: what evidential threshold must be reached to conclude that Walmart's conduct contributed to the workers' deaths and injuries?

3. The constraints on admissible evidence: what kinds of evidence will be considered to corroborate the thesis that Walmart contributed to the fire?

In cases dealing with ethical responsibility to address acute deprivation, Barry concludes, standards of application that err in favor of the most vulnerable are justified (Barry, 2003 , p. 221). As exemplified in the case of the Tazreen fire, the burden of proof should promote the interests of the workers over the interests of other actors.

\section{Benefit}

The beneficiary principle rests on the moral proposition that it is wrong to benefit from others' suffering and vulnerability or profit at another's expense (Anwander, 2005; Butt, 2007). We define the beneficiary principle as follows: agent $\mathrm{A}$, who knowingly benefited from an injustice caused by wrongful conduct regarding agent $\mathrm{B}$, acquires a moral duty to provide remedial justice to agent $\mathrm{B}$. The principle applies not only to cases in which agent A (the beneficiary) directly contributed to the injustice but also to situations in which agent A merely enables or perpetuates an already existing injustice or unintentionally benefits at the expense of agent B (Anwander, 2005, pp. 42-43). ${ }^{6}$

The scope of our beneficiary principle excludes incidental benefits and only includes benefits directly linked to the wrongs on which they counterfactually depend (Goodin \& Barry, 2014). Moreover, our definition draws on the wrongful enrichment understanding of the beneficiary principle, according to which the events that caused the injustice to agent B necessarily involved wrongful conduct, rather than innocent behavior, on the part of the beneficiary, agent A (Goodin \& Barry, 2014, p. 366). This approach is usually considered less controversial than its alternative, the unjust enrichment approach, which implicates agent A even when she was enriched by unjust but not wrongful activities (for example, a mistake or an oversight). In GSCs, the injustice suffered by workers (agents B) - that is, the violation of their basic labor rights - does not result from innocent mistakes but is caused in order to increase the products' attractiveness and profitability. Even unintentional tragedies, such as the death of 1134 workers in the Rana Plaza building collapse, result from continuous neglect and constant violation of health and safety standards intended to save costs.

The nature of the benefits to be gained from violating workers' rights in GSCs may be financial, ${ }^{7}$ caused by reduced payments, reduced safety expenses (Elliot \& Freeman, 2003), or by "squeezing" workers when enlarging production quantity (Anner, 2019; Chan \& Siu, 2010). States also gain financial benefits through mechanisms of taxation or capital growth (Cooney, 2015). Financial benefits are also gained by consumers, who purchase products at lower prices due to lower labor standards across the chain of production. While some consumers might not be aware of the unjust conditions under which the products they purchase are produced, those who are or should be aware of the labor rights violations bear responsibility under the principle of benefit; culpable ignorance is no excuse.

In addition, benefit may be measured by political gains. For example, higher employment rates, which could be achieved by the encouragement of labor-intensive factories

\footnotetext{
${ }^{6}$ Our conception of benefit does not include the relatively rare situations of "pure benefiting," where the benefiting actor in no way helps enable or perpetuate the injustice or benefits at the expense of these workers. These situations are not relevant to basic labor rights violations in GSCs.

${ }^{7}$ By benefit we mean actual benefit. One can ask whether actors who intended to benefit from wrongful acts should also be held responsible if the benefits did not materialize; however, the scope and stringency of such responsibility are beyond the framework of this discussion.
} 
in developing countries, may positively affect the local government's popularity.

\section{Capacity}

According to the capacity principle, the degree of responsibility individuals and institutions bear depends on their ability to remedy an existing unjust situation and end the particular harm without risking a high cost. Turning the famous ethical formula ascribed to Kant on its head, the capacity principle is based on the simple moral assumption of "can implies ought." In contrast to other principles in our set, which are backward looking in their nature, ${ }^{8}$ the capacity principle is forward looking. It focuses on the agents' ability to take concrete action to ameliorate the injustice, correct the harm done, or prevent its future occurrence. The classic example used to illustrate the principle is a man walking past a pond who sees a child drowning; from a moral perspective, the man ought to jump in and save the child, simply because he can (Singer, 1972).

Whether the principle retains its moral obligation when one transfers from the example of an individual drowning child to cases of global justice is a controversial question. Peter Singer argues that the geographical distance between those who suffer injustice and those who can alleviate or prevent their suffering should not affect the moral obligation (Singer, 1972, p. 232). Others argue that the application of the capacity principle should consider factors related to how the agent's ability was created. Suppose the ant achieved its capacity due to hard work, while the grasshopper was lazy all summer. Should the ant bear more responsibility simply because her ability is higher than the grasshopper's?

In the context of GSCs, existing economic and political realities may affect the operationalization of the capacity principle in various ways. For example, the effectiveness of different agents in remedying the situation depends on the relevant time frame, whether it requires a short-term alleviation of immediate injury, or long-term collaboration needed for structural reform (Sydow et al. 2021; Anner 2019). Considerations of costs are also significant, limiting the assignment of obligations that are too demanding. ${ }^{9}$ On the other hand, an agent may be more willing to bear higher costs (financial or political) if its action prevents a graver injustice.

\footnotetext{
${ }^{8}$ Barry views the contribution principle of responsibility as both backward- and forward-looking (Barry, 2005). We, by contrast, discuss the contribution principle as part of the five principles set and hence define it more narrowly, as a backward-looking principle.

9 On "duty dumping," see Buchanan and Decamp (2006).
}

\section{Power}

The principle of power refers to the inherent power that some agents have over others who participate in the same joint activity or shared practice. This power stems from structural causes rather than from the direct actions taken by these agents. Accordingly, agents who hold such structural power over others should bear greater responsibility for the latter's welfare.

Our definition rests on the conventional distinction between two traditional understandings of power: "power to" and "power over." The former usually refers to the agent's ability to act or achieve objectives. In Thomas Hobbes's words, power refers to the "means to obtain some future apparent good" (Hobbes [1651] 1996, p. 58), such as wealth, knowledge, or even friends. The second concept of power is relational, emphasizing the potential asymmetrical relationship between people. In Robert Dahl's words, "A has power over B to the extent that he can get B to do something that B would not otherwise do" (Dahl, 1957). Steven Lukes provides a similar definition: "A exercises power over B when A affects B in a manner contrary to B's interests" (Lukes, 1974, p. 30). This idea of "power over" underpins our principle of power. In contrast, the principle of capacity explained above resembles the notion of "power to," namely, the ability to remedy the violation of labor rights.

Our conception of power is not limited to the actual exercise of power over others. Instead, we view power as a dispositional concept, focusing on what the person holding power could do if he/she wished. For example, an employer may have the power to fire his employee even if he never uses this power. Moreover, our formulation of the principle of power, applied in the specific context of labor in GSCs, takes a more systemic and structural approach. In the sphere of labor, power relations between individuals should not be analyzed in isolation from each other. Instead, they should consider the changing dynamics of the structures and practices in which they are embedded (Young, 1980; Jugov, 2017; Lovett, 2009; Arnold and Hess 2017; Dallas et al., 2019). Applying the principle of power, thus, requires empirical investigation into the power relationships and domination stemming from the inherent power asymmetry between employers and workers, widely recognized as one of the main reasons for creating protective labor and employment legislation.

Another helpful way to think about the principle of power is through its mirror conception-the principle of vulnerability. According to Robert Goodin, we have special responsibilities for those who are particularly vulnerable to us (Goodin, 1985). He emphasizes the relational nature of the vulnerability principle; "Saying that $A$ is particularly vulnerable to $B$ with respect to $X$ clearly fingers $B$ as the agent who should be particularly responsible for seeing to 
Table 1 Priorities of principles for responsibility allocation according to the LMSR

\begin{tabular}{llll}
\hline & Scenario A & Scenario B & Scenario C \\
\hline Goal & $\begin{array}{c}\text { Immediate remedial } \\
\text { responsibility }\end{array}$ & $\begin{array}{c}\text { Final remedial } \\
\text { responsibility }\end{array}$ & $\begin{array}{l}\text { Responsibility to prevent } \\
\text { violations and promote labor } \\
\text { standards }\end{array}$ \\
$\begin{array}{l}\text { Main principles of respon- } \\
\text { sibility allocation }\end{array}$ & $\begin{array}{l}\text { Capacity } \\
\text { Connectedness }\end{array}$ & $\begin{array}{l}\text { Contribution } \\
\text { Benefit }\end{array}$ & $\begin{array}{l}\text { Power } \\
\text { Benefit } \\
\text { Connectedness }\end{array}$ \\
\hline
\end{tabular}

it that $A$ 's interests in $X$ are protected" (Goodin, 1985, p. 118). Modern labor law, according to Goodin, recognizes the inherent vulnerability of individual workers. Unionization of workers and state regulations are among the tools developed to address it, imposing special responsibilities on employers toward workers in most developed states. However, in contrast to direct power relations between an employer and its workers, this power is often held indirectly in GSCs. Lead companies, located at the top of the supply chain, exert indirect power over workers through suppliers, and affect workers' conditions on the production line (Coe \& Yeung, 2015; Fuller and Phelps, 2018; Smith, 2003; Lawford-Smith, 2018; Barrientos, 2013; Noronha et al., 2020). Lead firms may use their power to pressure suppliers to reduce costs, shorten deadlines, and increase the variety of products produced in smaller quantities. As a result, suppliers reduce workers' salaries, worsen their working conditions, and pressure them to work excessive hours (Anner, 2019; Locke, 2013; Merk, 2009).

The degree of power that lead firms exert over their suppliers may be measured by comparing the wealth (profits, for example) and the size (resources at the company's disposal) of the suppliers with those of the lead companies (Jungk, 2006, p. 10). Alternatively, power relations may be measured by the percentage of the supplier's annual revenue that comes from sales to the lead company. A lead company may have greater power over its supplier when it purchases greater percent of the supplier's products or services (Jungk, 2006, pp. 3-4).

In accordance with critical views in GPN research, the principle of power should also be examined on the international institutional level, given the power asymmetry that characterizes today's globalized world (Levy, 2008) and the extended power TNCs exert in international institutions and forums (Detomasi, 2007). G20 or G7 member countries, for example, have greater power to determine the rules and policies by which the IMF, WTO, or World Bank operate, and, thus, impact unjust working conditions worldwide.

\section{Relationships Between the Five Principles}

Next, we turn to the question of implementation. Generally, the five principles of responsibility allocation described above are meant to be implemented as a complete set. Indeed, if considered separately, different principles may yield conflicting conclusions concerning responsibility assignment. Taken as a set, the implementation of the five principles may have a cumulative effect, pointing to greater responsibility for some actors over others. Such accumulation is based on three parameters, which should be considered simultaneously. The first parameter is based on the number of principles that pertain to a particular actor. Thus, suppose actor A was found responsible for violation of labor standard $\mathrm{V}$ under all five principles. In that case, she should bear more responsibility than actor $\mathrm{B}$, who was found accountable according to only one or two principles. Compare, for example, the specific case of responsibility assigned to consumers and TNCs. Consumers should shoulder some responsibility, given their probable benefit from violations of labor standards that allow for reduced product prices, yet they are not responsible according to the other principles. TNCs, by contrast, may be found responsible according to all five principles and should, therefore, bear significantly higher responsibility to remedy the harm caused to workers.

The second parameter concerns the degree of responsibility assigned to different actors within each principle. Suppose, for example, actor A and actor B both benefited from the violation of labor standard $\mathrm{V}$ in the global supply chain $\mathrm{T}$, but actor A benefited significantly more (in material or political terms) than actor B. In that case, actor A should shoulder a greater portion of the responsibility to remedy violation $\mathrm{V}$.

The third parameter concerns the potential hierarchy among the different principles of responsibility allocation, an issue long debated by political philosophers (Barry, 2003; Brock, 2014; Goodin, 1985; Miller, 2007). Those who support prioritizing principles usually rely on normative and practical considerations, often depending on the particular practice under discussion. In this article, we do not rank the five principles in the abstract or as a general theoretical rule. Rather, we demonstrate how different principles may carry different weights under different circumstances. Table 1 provides examples for three different sets of priorities among 
our five principles, which depend on the different circumstances of labor rights violations under discussion. To clarify, prioritizing some principles of responsibility allocation under specific circumstances does not mean that only those principles should be taken into account. In the scenarios illustrated below, all five principles should be considered holistically, while some principles carry greater weight in the final calculation.

In scenario A, the main objective is to provide immediate remedy for the victims of labor rights violations. For example, in the case of a disaster or a need of urgent medical treatment. Under such circumstances, the principles of capacity and connectedness should be prioritized over the other three principles. When a disaster occurs, short-term and forward-looking considerations, such as who has the capacity to help the victims, should prioritize nuanced, backward-looking investigations concerning who is liable for causing the disaster. The local government, and in some cases the direct employers, usually have a higher capacity to send rescue forces and provide immediate aid to the victims.

Another relevant principle is the connectedness principle, according to which the workers' direct employer has greater responsibility to provide a prompt remedy due to the direct employment relations. However, the TNC, which is considered less connected on the interactional level as it does not have direct employment relations with the workers, may bear greater responsibility because of its greater financial capabilities. In scenario A, in sum, the capacity principle takes priority over all other principles, followed by the connectedness principle.

In contrast to scenario A, the goal of scenario B is to determine final responsibility for remedying the victims. Uncovering the existing injustice on both interactional and institutional levels requires a long-term, backward-looking investigation aimed at identifying the actors who contributed to the injustices. These actors should bear greater responsibility than actors who did not contribute to the unjust structure. Furthermore, those who benefited more from the wrongdoing should take greater responsibility than actors who did not benefit.

Last, in scenario C, the investigation's objective is to promote core labor standards and preventing future violations of labor rights. In contrast to cases where violations have already occurred, this forward-looking scenario assigns greater responsibility to actors who will most benefit from future violations and those who have the most power to determine labor conditions. Among the actors identified by the principles of benefit and power, those with greater connectedness to the potential victims should bear greater responsibility. In this scenario, greater responsibility in GSCs should be assigned to direct employers, actors who have "employer-like" characteristics, and local governments, which benefit from the violations and are more connected to the victims (due to their residency/citizenship) than foreign governments are.

One concern that arises when many actors share responsibility is the free-rider problem; some actors expect others to shoulder more responsibility so that they, in turn, can avoid their obligations. Indeed, this is a genuine concern inherent to the concept of shared responsibility. One way to address it is by viewing LMSR in political terms, including what Gunther Teubner calls "a duty of coordination" (Teubner, 2002). The idea of political responsibility means that all involved actors should cooperate and work together to discharge their shared responsibilities. Examples of such decentralized solutions may be found in France, for example, where the health and social security law imposes on each actor a duty of coordination in the network. Breaching this duty is sanctioned with responsabilité solidaire (Teubner, 2002).

\section{From Moral Duties to Legal Commitments}

The LMSR highlights the central place that TNCs and brands' home states hold in the "responsibility gap" characterizing current global labor governance- the gap between moral and formal responsibilities held by actors involved in GSCs. Practical steps to narrow the responsibility gap should include strengthening formal legal, sanction-based, abilities of relevant players to promote workers' standards throughout the network and significant reform of existing regulations on both transnational and national levels. An illuminating demonstration of the advantages of such legally binding arrangements can be found in the experience of the Accord on Building and Fire Safety created in Bangladesh the aftermath of the 2013 Rana Plaza disaster (Reinecke \& Donaghey, 2015). ${ }^{10}$

A multilateral industry-labor agreement between apparel brands and retailers, global trade union federations, and local Bangladeshi garment worker union federations, the Accord rests on a conception of responsibility that goes beyond individual liability. Rather, it incorporated capacity, connectedness, and power considerations, for example by allocating funding requirements based on the company's volume of outsourcing from Bangladesh, or by lead firms' agreement to shoulder some of the supplier's financial burdens required for compliance with the Accord safety standards. Initially, the Accord reflected optimistic expectations that under conditions of consistent state failure to enforce workers'

\footnotetext{
10 The 2018 Transition Accord replaced the original 2013 agreement and extended the agreement through May 31st, 2021, and then extended again for three months to allow for negotiations to continue to identify a lasting arrangement. See http://bangladeshaccord.org/ (last visited July 3rd, 2021).
} 
rights effectively, TNCs would take the role of the ultimate enforcer of basic labor standards (Donaghey \& Reinecke, 2018). Unfortunately, these expectations only partially materialized. During the first years following the Accord commencement, signatory buyers and suppliers alike displayed little willingness to engage in costly reconstructions required under the Accord safety standards. However, compliance increased dramatically when the Accord's legal enforcement mechanisms were invoked, including widespread termination of sourcing contracts with non-compliant suppliers and two settlements resulting in large compensation payments by non-compliant TNCs (Bair et al., 2020; Blasi \& Bair, 2019; Anner 2020). The Accord, therefore, exposed both the limitations of voluntary private regulations and the importance of complementing them with enforcement mechanisms.

Further strengthening of sanction-based legal regulations could take place on both national and international levels. Nationally, such regulations may include, for example, due diligence laws or courts' applications of transnational jurisdictions. The last half decade witnessed minor reforms in this direction, especially in Europe. France, for example, enacted in March 2017 a new Corporate Duty of Vigilance Law that established legally binding obligations for French companies or their subsidiaries to identify and prevent adverse human rights and environmental impacts resulting from their activities in France or abroad. The law applies to all companies headquartered in France that employ more than five thousand employees or are headquartered abroad and employ more than ten thousand employees worldwide. It requires that these firms set up a plan that "includes reasonable vigilance measures to identify risks and prevent serious violations of human rights and fundamental freedoms, health and safety of persons and environment resulting from the activities of the company and of the companies it controls, either directly or indirectly, as well as the activities of subcontractors or suppliers with whom an established business relationship is maintained" (Cossart et al., 2017; Lewis, 2017). The French Constitutional Council decided that even though a company cannot be fined if it does not establish a vigilance plan or does not comply with its vigilance plan, breach of the duty of care may still entail liability for the company. Specifically, victims may bring action in France even if the harm occurred in a territory outside France. ${ }^{11}$

Another relevant legal development occurred in Germany in the court case of Jabir and Others v. KiK (Wesche \& Saage-Maaß, 2016), in which the regional court of Dortmund set an international precedent by accepting jurisdiction

\footnotetext{
11 Other similar proposals were raised in Switzerland and by the Swiss Coalition for Corporate Justice. See https://corporatejustice.ch/ about-the-initiative/.
}

in a case from a textile factory in Karachi, Pakistan, and granting legal aid to four of its workers who filed a compensation claim against the German clothing retailer KiK. The Dortmund court was the first in the history of sweatshops to consider the legal responsibility of a Western-based brand for the violation of labor standards in a production factory abroad while recognizing no direct employer-employee relationship between the two parties. ${ }^{12}$ The Dortmund court's decision was compatible with broader EU endorsement of extraterritorial obligations to protect human rights, expressed by the adoption of the 2011 Maastricht Principles on Extraterritorial Obligations of States in the Area of Economic, Social and Cultural Rights (Skogly, 2017). In other countries, however, most notably in the United States, the political and legal systems maintain their resistance to national enforcement of extraterritorial labor and human rights commitments, as exemplified most recently by the US Supreme Court ruling regarding the Alien Tort Statute. Nestlé corporation had purchased cocoa from plantations in Côte d'Ivoire using child slave labor; the court ruled that the former slaves had no standing to sue in a US court. ${ }^{13}$

On the international level, further strengthening of compliance-based approaches may be achieved by creating comprehensive international and transnational enforcement mechanisms through international institutions such the ILO, the $\mathrm{UN}$, and the WTO. A detailed discussion of such a scheme is beyond the scope of this paper. To give two relatively politically feasible examples, the ILO could transcend its traditional role and provide a "coordinated governance" scheme which would mobilize firms, unions, civil society organizations, and governments to cooperate and work together (Posthuma \& Rossi, 2017). In 2016, during the ILC's concluding discussion on decent work in GSCs, the ILO was granted a formal mandate by its constituencies to pursue a legally binding convention on GSCs (Thomas \& Turnbull, 2018). In theory, the ILO could leverage this new convention to develop tools that facilitate enforceable multi-stakeholder arrangements such as multi-firm TIRAs (Ashwin et al., 2020) and other mechanisms to institutionalize and facilitate worker-driven supply chain governance (Reinecke \& Donaghey, 2015; Blasi \& Bair, 2019). ILO involvement could, inter alia, ensure sustainable industry-wide participation of TNCs within such schemes, which would help prevent competitive pressures on participating firms (Oka et al. 2020; Ahlquist \& Mosely, 2021; Schuessler et al., 2019). The ILO could supplementarily extend its existing multi-shareholder programs (Pike, 2020) and supervisory mechanisms (Dahan et al., 2013).

\footnotetext{
${ }^{12}$ In January 2019, the regional court ruled that the statute of limitations had expired, and the claimants were, therefore, unable to seek a judicial remedy. https://www.business-humanrights.org/en/kik-lawsu it-re-pakistan.

13 Nestlé USA, Inc. v. John Doe I, 593 U. S. (2020).
} 
Bolstering the UNGP Framework by adopting a legally binding UN Convention or other national mandatory measures could present another way forward (Deva \& Bilchitz, 2017; Trebilcock, 2020; Wettstein, 2012, 2021). Indeed, in recent years, a growing number of states have begun to challenge the narrow conception of business responsibility underpinning the existing international order. In particular, a loud opposition has emerged against the UNGP, which were criticized for distinguishing between the broad duties of states to protect human rights and the limited responsibility of businesses to merely respect human rights (Trebilcock, 2020; Wettstein, 2021). The LMSR presented in this article could help explicate the normative responsibility framework underlining the proposed drafts, potentially contributing to the discussion on the treaty's legal force or the scope of TNCs' due diligence responsibilities.

\section{Conclusion}

The LMSR presented in this article rests on the idea that all actors who participate in or affect (directly or indirectly) labor conditions in GSCs should shoulder responsibility for the promotion and protection of labor standards. This moral idea could be applied through various institutional and legally binding mechanisms based on a combination of private and public regulations. However, significant additional research is still needed to better understand the various avenues through which our normative model could be implemented empirically, given the wide range of governance types characterizing current GSCs (Gereffi \& Rasche, 2007; Provan \& Kenis 2008) and the differences between the various regions and industries in which they operate.

Generally, this article contributes to the comprehensive discussion on labor governance in GSCs by proposing a normative framework for thinking about responsibility for the promotion and protection of labor standards. While some analysts project that the economic downturn caused by the COVID-19 pandemic will lead to a shrinking of GSCs and the renationalization of production (Javorcik, 2020), this form of globalized economic enterprise will continue to provide jobs for millions of workers around the world (OECD, 2020). Further research is needed to more tightly bridge the existing disciplinary divide between the rich empirical literature in political economy, economic geography, and management of GSCs and the normative discussion in political theory on responsibility and global justice. Such a multi-disciplinary approach is necessary to advance our understating and broaden our perspective on the morally appropriate, yet also economically, politically, and legally feasible, solutions to labor rights violations in the globalized economy.

Acknowledgements The authors would like to extend special thanks to Thomas Pogge, Jillian Brock, Mark Anner, Kevin Kolben, and Radu
Mares for invaluable comments on early versions of the paper. We are also grateful for helpful suggestions we received from the participants of the workshop on "Justice and Labor Rights in the Global Era" (Israel 2019); Heidelberg Max Plank conference on "Transnational Labour Law in an Era of Rising Nationalism"; APSA panel on "Coming to Grips with Injustice"; Bonn conferenceon "SDGs and Human Rights"; Hebrew University's Political Philosophy Seminar; Global Justice Workshop, Yale University; and from the editors and anonymous reviewers at JBE. Jacki Silbermann, Alex Peterson, Noa Ovadia and Lihi Yona provided excellent research assistance.

Funding The authors have no relevant financial or non-financial interests to disclose. All authors certify that they have no affiliations with or involvement in any organization or entity with any financial interest or non-financial interest in the subject matter or materials discussed in this manuscript. The authors have no financial or proprietary interests in any material discussed in this article.

\section{Declarations}

Conflict of interest The authors have no conflicts of interest to declare that are relevant to the content of this article.

\section{References}

Aßländer, M. S. (2020). How to overcome structural injustice? Social connectedness and the tenet of subsidiarity. Journal of Business Ethics, 162, 719-732.

Agusti-Panareda, J., Ebert, F. C., \& LeClercq, D. (2015). ILO labor standards and trade agreements: A case for consistency. Comparative Labor Law and Policy Journal, 36(3), 347-380.

Ahlquist, J. S., \& Mosley, L. (2021). Firm participation in voluntary regulatory initiatives: The accord, alliance, and US garment importers from Bangladesh. The Review of International Organizations, 16, 317-343.

Alston, P. (2004). 'Core labour standards' and the transformation of the international labour rights regime. European Journal of International Law, 15(3), 457-521.

Anner, M. (2015). Labor control regimes and worker resistance in global supply chains. Labor History, 56(3), 292-307.

Anner, M. (2019). Squeezing workers' rights in global supply chains: Purchasing practices in the Bangladesh garment export sector in comparative perspective. Review of International Political Economy, 27(7), 320-347.

Anner, M. (2020). Abandoned? The impact of Covid-19 on workers and businesses at the bottom of global garment supply chains. Center for Global Workers' Rights.

Anner, M., Bair, J., \& Blasi, J. (2013). Toward joint liability in global supply chains: Addressing the root causes of labor violations in international subcontracting networks. Comparative Labor Law and Policy Journal, 35, 1.

Anwander, N. (2005). Contributing and benefiting: Two grounds for duties to the victims of injustice. Ethics and International Affairs, 19(1), 39-45.

Arnold, D., \& Hess, M. (2017). Governmentalizing Gramsci: Topologies of power and passive revolution in Cambodia's garment production network. Environment and Planning A: Economy and Space, 49(10), 2183-2202.

Ashwin, S., Oka, C., Schuessler, E., Alexander, R., \& Lohmeyer, N. (2020). Spillover effects across transnational industrial relations agreements: The potential and limits of collective action in global supply chains. ILR Review, 73(4), 995-1020. 
Bair, J., Anner, M., \& Blasi, J. (2020). The political economy of private and public regulation in post-Rana Plaza Bangladesh. ILR, 73(4), 969-994.

Bair, J., \& Palpacuer, F. (2012). From varieties of capitalism to varieties of activism: The antisweatshop movement in comparative perspective. Social Problems, 59(4), 522-543.

Bakker, F. G. A. D., Rasche, A., \& Ponte, S. (2019). Multi-stakeholder initiatives on sustainability: A cross-disciplinary review and research agenda for business ethics. Business Ethics Quarterly, 29(3), 343-383.

Barrientos, S. W. (2013). 'Labour chains': Analysing the role of labour contractors in global production networks. The Journal of Development Studies, 49(8), 1058-1071.

Barrientos, S. W., \& Smith, S. (2007). Do workers benefit from ethical trade? Assessing codes of labour practice in global production systems. Third World Quarterly, 28(4), 713-729.

Barry, C. (2003). Global justice: Aims, arrangements, and responsibilities. In T. Erskine (Ed.), can institutions have responsibilities? Collective Moral Agency and International Relations (pp. 218-238). Palgrave Macmillan.

Barry, C. (2005). Applying the contribution principle. Metaphilosophy, 36, 210-227.

Barry, C., \& Øverland, G. (2016). Responding to global poverty: Harm. Cambridge University Press.

Barry, C., \& Reddy, S. (2008). International trade and labor standards. Columbia University Press.

Bartley, T. (2005). Corporate accountability and the privatization of labor standards: Struggles over codes of conduct in the apparel industry. Research in Political Sociology, 12, 211-244.

Bartley, T., \& Egels-Zandén, N. (2015). Responsibility and neglect in global production networks: the uneven significance of codes of conduct in Indonesian factories. Global Networks, 15, S21-S44.

Beitz, C. R. (2004). Human rights and the law of peoples. In D. K. Chatterjee \& D. MacLean (Eds.), The ethics of assistance: Morality and the distant needy (pp. 193-214). Cambridge University Press.

Berliner, D., Greenleaf, A. R., Lake, M., Levi, M., \& Noveck, J. (2015). Labor standards in international supply chains: Aligning rights and incentives. Edward Elgar.

Bird, R. C. (2005). Employment as a relational contract. University of Pennsylvania Journal of Labor and Employment Law, 8(1), 149-217.

Blasi, J., \& Bair, J. (2019). An analysis of multiparty bargaining models for global supply chains. Conditions of work and employment series, (105). ILO.

Brishen, R. (2016). Law and the global sweatshop problem. In R. P. Appelbaum \& N. Lichtenstein (Eds.), Achieving workers' rights in the global economy (pp. 137-151). Cornell University Press.

Brock, G. (2014). Global poverty, decent work and remedial responsibility. In D. Meyers (Ed.), Poverty, coercion, and human rights (pp. 119-145). Oxford University Press.

Brock, G. (2016). Consumer complicity and labor exploitation. Croatian Journal of Philosophy, 16(46), 113-125.

Buchanan, A., \& DeCamp, M. (2006). Responsibility for global health. Theoretical Medicine and Bioethics, 27(1), 95-114

Burt, S., Johansson, U., \& Dawson, J. (2017). Dissecting embeddedness in international retailing. Journal of Economic Geography, $17,685-707$.

Butt, D. (2007). On benefiting from injustice. Canadian Journal of Philosophy, 37(1), 129-152.

Chan, A., \& Siu, K. (2010). Analyzing exploitation. Critical Asian Studies, 42(2), 167-190.

Chen, M. (2020). Disaster looms as the coronavirus disrupts the garment supply chain. The Nation. https://www.thenation.com/artic le/economy/garment-supply-chain-coronavirus/.
Coe, N., Dicken, P., \& Hess, M. (2008). Global production networks: Realizing the potential. Journal of Economic Geography, 8(3), 271-295.

Coe, N., \& Hess, M. (2013). Global production network, labour and development. Geoforum, 44, 4-9.

Coe, N., \& Yeung, H.W.-C. (2015). Global production networks: Theorizing economic development in an interconnected world. Oxford University Press.

Coe, N., \& Yeung, H.W.-C. (2018). Global production networks: Mapping recent conceptual developments. Journal of Economic Geography., 19, 775-801.

Compa, L. (2008). Corporate social responsibility and workers' rights. Comparative Labor Law and Policy Journal, 30(1), 1-11.

Cooney, S. (2015). China's challenge to labour law in both the global north and the global south. In A. Blackett \& A. Trebilcock (Eds.), Research handbook on transnational labor law. Edward Elgar.

Cossart, S., Chaplier, J., \& De Lomenie, T. B. (2017). The French law on duty of care: A historic step towards making globalization work for all. Business and Human Rights Journal, 2(2), 317-323.

Dahan, Y., Lerner, H., \& Milman-Sivan, F. (2011). Global justice, labor standards and responsibility. Theoretical Inquiries in Law, 12(2), 117-142.

Dahan, Y., Lerner, H., \& Milman-Sivan, F. (2013). Shared responsibility and the international labor organization. Michigan Journal of International Law, 34(4), 675-743.

Dahan, Y., Lerner, H., \& Milman-Sivan, F. (2016). Global justice and international labour rights. Cambridge University Press.

Dahl, R. (1957). The concept of power. Behavioral Science, 2(3), 201-215.

Dallas, M. P., Ponte, S., \& Sturgeon, T. J. (2019). Power in global value chains. Review of International Political Economy, 26(4), 666-694.

D’Cruz, P., Noronoha, E., Banday, M. U. L., \& Chakraborty, S. (2021). Place matters: (Dis)embeddedness and child labourers' experience of depersonalized bullying in Indian Bt Cottonseed Global Production Networks. Journal of Business Ethics. https://doi.org/ 10.1007/s10551-020-04676-1

Deva, S., \& Bilchitz, D. (Eds.). (2013). Human rights obligations of business: Beyond the corporate responsibility to respect? Cambridge University Press.

Deva, S., \& Bilchitz, D. (2017). Building a treaty on business and human rights: Context and contours. Cambridge University Press.

Detomasi, D. A. (2007). The multinational corporation and global governance: Modelling global public policy networks. Journal of Business Ethics, 71, 321-334.

Distelhorst, G., Locke, R. M., Pal, T., \& Samel, H. (2015). Production goes global, compliance stays local. Regulation and Governance, 9, 224-242.

Donaghey, J., \& Reinecke, J. (2018). When industrial democracy meets corporate social responsibility: A comparison of the Bangladesh accord and alliance as responses to the Rana Plaza disaster. British Journal of International Relations, 56(1), 14-42.

Elliot, K. A., \& Freeman, R. B. (2003). Can labor standards improve under globalization? Peterson Institute Press.

Ebert, C. F., \& Novitz, T. (2020). Introduction: International institutions, public governance and future regulation of work. International Organizations Law Review, 17, 1-9.

ETO. (2011). Maastricht principles on extraterritorial obligations of states in the area of economic, social and cultural rights. https:// www.etoconsortium.org/nc/en/main-navigation/library/maast richt-principles/?tx_drblob_pi1\%5BdownloadUid $\% 5 \mathrm{D}=23$

Fichter, M., Helfen, M., \& Sydow, J. (2011). Regulating labor relations in global production networks: Insights on international 
framework agreements. Internationale Politik Und Gesellschaft, 2, 69-86.

Fuller, C., \& Phelps, N. A. (2018). Revisiting the multinational enterprise in global production networks. Journal of Economic Geography, 18(1), 139-161.

Gereffi, G. (2014). Global value chains in a post-Washington consensus world. Review of International Political Economy, 21(1), 9-37.

Gereffi, G. (2018). Global value chains and development: Redefining the contours of 21 st century.

Gereffi, G., \& Frederick, S. (2010). The global apparel value chain, trade and the crisis: Challenges and opportunities for developing countries. In O. Cattaneo, G. Gereffi, \& C. Staritz (Eds.), Global value chains in a postcrisis world: A development perspective (pp. 157-208). World Bank.

Gilbert, D. U., \& Rasche, A. (2007). Discourse ethics and social accountability: The ethics of SA 8000. Business Ethics Quarterly, 17(2), 187-216.

Goodin, R. E. (1985). Protecting the vulnerable: A re-analysis of our social responsibilities. University of Chicago Press.

Goodin, R. E., \& Barry, C. (2014). Benefiting from the wrongdoing of others. Journal of Applied Philosophy, 31(4), 363-376.

Greenhouse, S. (2012). Documents indicate walmart blocked safety push in Bangladesh. New York Times. https://www.nytimes. com/2012/12/06/world/asia/3-walmart-suppliers-made-goodsin-bangladeshi-factory-where-112-died-in-fire.html.

Haydar, B. (2005). Extreme poverty and global responsibility. In C. Barry \& T. Pogge (Eds.), Global institutions and responsibilities: Achieving global justice (pp. 310-322). Blackwell.

Helfen, M., \& Fichter, M. (2013). Building transnational union networks. British Journal of Industrial Relations, 51, 553-576.

Helfen, M., Schüßler, E., \& Sydow, J. (2018). How Can Employment Relations in Global Value Networks be Managed towards Social Responsibility? Human Relations, 71(12), 1640-1665.

Hepple, B. (2005). Labor laws and global trade. Hart Publishing.

Henderson, J., Dicken, P., Hess, M., Coe, N., \& Yeung, H. W. C. (2002). Global production networks and the analysis of economic development. Review of International Political Economy, 9(3), 436-464.

Hess, M. (2004). 'Spatial' relationships? Towards a reconceptualization of embeddedness. Progress in Human Geography, 28(2), $165-186$.

Hobbes, T. [1651] 1996. Leviathan. Oxford University Press.

Jenkins, R. (2005). Globalization, corporate social responsibility and poverty. International Affairs., 81(3), 525-540.

Javorcik, B. (2020). Global supply chains will not be the same in the post-COVID-19 world. In R. Baldwin \& S. Evenett (Eds.), COVID-19 and trade policy: Why turning inward won't work (Chapter 8). CEPR Press.

ILO. (1998). Declaration on Fundamental Principles and Rights at Work.

ILO. (2019). ILO centenary declaration for the future of work. In International labour conference 108th session. International Labour Office.

James, A. (2012). Fairness in practice: A social contract for a global economy. Oxford University Press.

Jugov, T. (2017). Systemic domination as ground of justice. European Journal of Political Theory, 19(1), 47-66.

Jungk, M. (2006). Complicity in human rights violations: A responsible business approach to suppliers. Danish Institute for Human Rights.

Kolben, K. (2015). Dialogic labor regulation in the global supply chain. Michigan Journal of International Law, 36(3), 425-466.

Kolben, K. (2019). The consumer imaginary: Labor rights, human rights, and citizen-consumers in the global supply chain. Vanderbilt Journal of Transnational Law, 52(4), 839-898.
Lakhani, T., Kuruvilla, S., \& Avgar, A. (2013). From the firm to the network. British Journal of Industrial Relations, 51, 440-472.

Langille, B. A. (2003). Re-reading the preamble to the 1919 ILO constitution in light of recent data on FDI and s. Columbia Journal of Transnational Law, 42, 87-99.

Lashitew, A. A., Bals, L., \& van Tulder, R. (2020). Inclusive Business at the Base of the Pyramid: The Role of Embeddedness for Enabling Social Innovations. Journal of Business Ethics, $162,421-448$

Lawford-Smith, H. (2018). Does purchasing make consumers complicit in global labour injustice? Res Publica, 24, 319-338.

Lee, S. H., Mellahi, K., Mol, M. J., \& Pereira, V. (2017). No-sizefits-all: Collaborative governance as an alternative for addressing labour issues in global supply chains. Journal of Business Ethics, 162(2), 291-305.

Levy, D. L. (2008). Political contestation in global production networks. Academy of Management Review, 33(4), 943-963.

Lewis, M. (2017). French companies must show duty of care for human and environmental rights. Morgan Lewis. https://www. morganlewis.com/pubs/2017/04/french-companies-must-showduty-of-care-for-human-and-environmental-rights.

Locke, R. (2013). The promise and limits of private power: Promoting labor standards in a global economy. Cambridge University Press.

Locke, R., Amengual, M., \& Mangla, A. (2009). Virtue out of necessity? Compliance, commitment, and the improvement of labor conditions in global supply chains. Politics and Society, 37(3), 319-351.

Locke, R., \& Samel, H. (2018). Beyond the workplace: "Upstream" business practices and labor standards in the global electronics industry. Studies in Comparative International Development, $53,1-24$.

Lovett, F. (2009). Domination and distributive justice. Journal of Politics, 71(3), 817-830.

Lund-Thomsen, P. (2020). Corporate social responsibility: A supplier-centered perspective. Environment and Planning a: Economy and Space, 52(8), 1700-1709.

Lund-Thomsen, P., \& Lindgreen, A. (2014). Corporate social responsibility in global value chains: Where are we now and where are we going? Journal of Business Ethics, 123(1), 11-22.

Lunney, M., Nolan, D., \& Oliphant, K. (2017). Tort law: Text and materials. Oxford University Press.

Lukes, S. (1974). Power: A Radical Approach. Macmillan.

Macneil, I. R. (2000). Contracting worlds and essential contract theory. Society and Legal Studies, 9(3), 431-438.

Mayer, R. (2007). Sweatshops, exploitation, and moral responsibility. Journal of Social Philosophy, 38(4), 605-619.

Melo Araujo, B. (2018). Labour provisions in EU and US megaregional trade agreements: Rhetoric and reality. International and Comparative Law Quarterly, 67(1), 233-253.

Mena, S., \& Palazzo, G. (2012). Input and output legitimacy of multi-stakeholder initiatives. Business Ethics Quarterly, 22(3), 527-556.

Merk, J. (2009). Jumping scale and bridging space in the era of corporate social responsibility: Cross-border labour struggles in the global garment industry. Third World Quarterly, 30(30), $599-615$.

Miller, D. (2001). Distributing responsibilities. Journal of Political Philosophy, 9(4), 453-471.

Miller, D. (2007). National responsibility and global justice. Oxford University Press.

Miller, R. (2010). Globalizing Justice: The Ethics of Poverty and Power. Oxford University Press.

Noronha, E., D'cruz, P., \& Banday, M. U. L. (2020). Navigating embeddedness: Experiences of Indian IT suppliers and employees in the Netherlands. Journal of Business Ethics, 164, 95-113. 
OECD. (2020). COVID-19 and global value chains: Policy options to build more resilient production networks. OECD.org http:// www.oecd.org/coronavirus/policy-responses/covid-19-andglobal-value-chains-policy-options-to-build-more-resilient-produ ction-networks-04934ef4/.

Oka, C., Egels-Zandén, N., \& Alexander, R. (2020). Buyer engagement and labour conditions in global supply chains: The Bangladesh accord and beyond. Development and Change, 51, 1306-1330.

O'Rourke, D. (2003). Outsourcing regulation: Analyzing nongovernmental systems of labor standards and monitoring. Policy Studies Journal, 31, 1-29.

O'Rourke, D. (2006). Multi-stakeholder regulation: Privatizing or socializing global labor standards? World Development, 34(5), 899-918.

Overdevest, C., \& Zeitlin, J. (2014). Assembling an experimentalist regime: Transnational governance interactions in the forest sector. Regulation and Governance, 8, 22-48.

Pike, K. (2020). Voice in supply chains: Does the better work program lead to improvements in labor standards compliance? ILR Review, 73(4), 913-938.

Pogge, T. (2002). World poverty and human rights: Cosmopolitan responsibilities and reforms. Boca Raton: Polity Press.

Posthuma, A., \& Nathan, D. (Eds.). (2010). Labour in global production networks in India. Oxford University Press.

Posthuma, A., \& Rossi, A. (2017). Coordinated governance in global value chains: Supranational dynamics and the role of the international labour organization. New Political Economy, 22(2), 186-202.

Powell, B., \& Zwolinski, M. (2012). The ethical and economic case against sweatshop labor: A critical assessment. Journal of Business Ethics, 107(4), 449-472.

Preiss, J. (2019). Freedom, autonomy, and harm in global supply chains. Journal of Business Ethics, 160(4), 881-891.

Provan, K. G., \& Kenis, P. (2008). Modes of network governance: Structure, management, and effectiveness. Journal of Public Administration Research and Theory, 18(2), 229-252.

Rasche, A. (2010). The limits of corporate responsibility standards. Business Ethics, 19(3), 280-291.

Rasche, A., \& Waddock, S. (2021). The UN guiding principles on business and human rights: Implications for corporate social responsibility research. Business and Human Rights Journal, 6, 227-240.

Rawls, J. A. (1971). Theory of justice. Harvard University Press.

Reader, S. (2003). Distance, relationship and moral obligation. The Monist, 86(3), 367-381.

Reinecke, J., \& Donaghey, J., et al. (2015). The 'accord for fire and building safety in Bangladesh' in response to the Rana Plaza disaster. In A. Marx (Ed.), Global governance of labour rights: Assessing the effectiveness of transnational public and private policy initiatives (pp. 257-277). Edward Elgar.

Risse, M., \& Wollner, G. (2019). On trade justice. Oxford University Press.

Rodríguez-Garavito, C. A. (2005). Global governance and labor rights: Codes of conduct and anti-sweatshop struggles in global apparel factories in Mexico and Guatemala. Politics and Society, 33(2), 203-333.

Ruggie, J. (2014). International legalization in business and human rights. Remarks at the Washington Foreign Law Society's Jones award presentation.

Salomon, M. (2007). Global responsibility for human rights. Oxford University Press.

Sangiovanni, A. (2007). Justice and the priority of politics to morality. Journal of Political Philosophy, 16(2), 137-164.

Scheffler, S. (2001). Boundaries and allegiances: Problems of justice and responsibility in liberal thought. Oxford University Press.
Schuessler, E., Frenkel, S., Ashwin, S., Kabeer, N., Egels-Zandén, N., Alexander, R., \& Rahman, K. M. (2019). Garment supply chains since Rana Plaza: Governance and worker outcomes. Garment supply chain governance project final report. http://hdl.handle. net/2066/215124

Seidman, G. (2007). Beyond the boycott: Labor rights, human rights, and transnational activism. Russell Sage.

Singer, P. (1972). Famine, affluence and morality. Philosophy and Public Affairs, 1(3), 229-243.

Skogly, S. (2017). Regulatory obligations in a complex world. In S. Deva \& D. Bilchitz (Eds.), Building a treaty on business and human rights: Context and contours (pp. 318-345). Cambridge University Press.

Smith, A. (2003). Power relations, industrial clusters, and regional transformations: Pan-European integration and outward processing in the Slovak clothing industry. Economic Geography, $79(1), 17-40$.

Snyder, J. C. (2008). Needs exploitation. Ethical Theory and Moral Practice, 11(4), 389-405.

Sobel-Read, K. B. (2014). Global value chains: A framework for analysis. Transnational Legal Theory, 5(3), 364-407.

Sollars, G. G., \& Englander, F. (2018). Sweatshops: Economic analysis and exploitation as unfairness. Journal of Business Ethics, 149(1), 15-29.

Soundararajan, V., Brown, J. A., \& Wicks, A. C. (2019). Can multistakeholder initiatives improve global supply chains? Improving deliberative capacity with a stakeholder orientation. Business Ethics Quarterly, 29(3), 385-412.

Soundararajan, V., Sahasranamam, S., Khan, Z., \& Jain, T. (2021). Multinational enterprises and the governance of sustainability practices in emerging market supply chains: An agile governance perspective. Journal of World Business, 56(2), 101-149.

Stone, K. V. W. (2008). Three challenges for labor rights in our time. In C. Estlund \& B. Bercusson (Eds.), Regulating labor in the wake of globalization (pp. 119-121). Hart Publishing.

Sydow, J., Schüßler, E., \& Helfen, M. (2021). Managing global production networks: Towards social responsibility via inter-organizational reliability? In L. Biggiero, D. de Jongh, D. Fischer, B. P. Priddat, J. Wieland, \& A. Zicari (Eds.), Economics-The relational view: Interdisciplinary contributions to an emerging field of research. Springer.

Teubner, G. (2002). Hybrid laws: Constitutionalizing private governance networks. In R. Kagan, M. Krygier, \& K. Winston (Eds.), Legality and community: On the intellectual legacy of Philip Selznick (pp. 311-332). Rowman and Littlefield.

Thomas, H., \& Turnbull, P. (2018). From horizontal to vertical labour governance: The International Labour Organization (ILO) and decent work in global supply chains. Human Relations, 71(4), $536-559$.

Trebilcock, A. (2020). The Rana Plaza disaster seven years on: Transnational experiments and perhaps a new treaty? International Labour Review, 159, 545-568.

Van Buren III, H. J., Schrempf-Stirling, J., \& Westermann-Behaylo, M. (2021). Business and human trafficking: A social connection and political responsibility model. Business and Society, 60(2), $341-375$

Waddock, S. (2008). Building a new institutional infrastructure for corporate responsibility. AMP, 22, 87-108.

Walzer, M. (1983). Spheres of justice. Basic Books.

Wesche, P., \& Saage-Maaß, M. (2016). Holding companies liable for human rights abuses related to foreign subsidiaries and suppliers before German Civil courts: Lessons from Jabir and others v KiK. Human Rights Law Review, 16(2), 370-385.

Wettstein, F. (2010). The duty to protect: Corporate complicity, political responsibility, and human rights advocacy. Journal of Business Ethics, 96(1), 33-47. 
Wettstein, F. (2012). CSR and the debate on business and human rights: Bridging the great divide. Business Ethics Quarterly, 22(4), 739-770.

Wettstein, F. (2020). Multinational corporations and global justice. Stanford University Press.

Wettstein, F. (2021). Betting on the wrong (Trojan) horse: CSR and the implementation of the UN guiding principles for business and human rights. Business and Human Rights Journal, 6, 1-14.

World Economic Forum. (2015). A new paradigm: Shared responsibility for supply chains. Global Agenda Council on Human Rights.

WRC (2020). Covid-19 tracker: Which brands are acting responsibly toward suppliers and workers? https://www.workersrights.org/ issues/covid-19/tracker/
Young, I. M. (1980). Justice and the politics of difference. Princeton University Press.

Young, I. M. (2004). Responsibility and global labor justice. Journal of Political Philosophy, 12(4), 365-388.

Young, I. M. (2010). Responsibility for justice. Oxford University Press.

Publisher's Note Springer Nature remains neutral with regard to jurisdictional claims in published maps and institutional affiliations. 